\title{
Palestinians and Donors Playing with Fire: 25 Years of Water Projects in the West Bank
}

Trottier, Julie

Centre National de la Recherche Scientifique, ART-Dev, Montpellier, France

Site Saint-Charles

Université Paul Valéry

34199 Montpellier

FRANCE

julie.trottier@cnrs.fr

Rondier, Anaïs

Centre National de la Recherche Scientifique, ART-Dev, Montpellier, France

Site Saint-Charles

Université Paul Valéry

34199 Montpellier

FRANCE

Anais.rondier@sciencespo.fr

Perrier Jeanne

University Paul Valéry, ART-Dev, Montpellier, France

Site Saint-Charles

Université Paul Valéry

34199 Montpellier

FRANCE

Jeanne.perrier@sciencespo.fr 


\begin{abstract}
:
This article explores how Palestinian led, donor supported water projects have transformed societal interactions concerning water since 1994. It distinguishes spatial, institutional and sectoral trajectories of water and explores the impacts on each type of trajectory. It demonstrates that the overall impact of these projects is more than the sum total of the individual projects. All together, they entail territorial change. Wastewater and reuse projects transform the largest flows and have the greatest impact on water trajectories. Overall, the recharge of the upper unconfined aquifer is compromised, with the effect that grass-root farmer institutions managing it are negatively affected.
\end{abstract}

Keywords: water projects; Palestinian water; water governance; territorial change; water infrastructure 


\section{Introduction}

What happens when a small territory such as the West Bank becomes the focus of donor funding in an unprecedented manner? Since 1994, donors have been supporting the Palestinian Authority (PA), ultimately making it far more accountable to them than to its constituency (Brynen, 2000) (Keating, Le More, \& Lowe, 2005) (Le More, 2008) (Nakhleh, 2012). The case of development projects concerning water is especially salient. In a semi-arid environment, a society necessarily devises rules to manage its interactions with water. Infrastructure projects, no matter how well intentioned, unavoidably alter these interactions, often inadvertently undermining many actors and processes they sought to support (Harvey, Jensen, \& Morita, 2017). Since 1994, donors supported over 2000 projects concerning water in the West Bank. This article explores the overall transformations they have entailed.

Research in the political ecology of water often reiterates that the flow of water connects all socio-spatial relations. It pays great attention to the production of the hydro-social cycle as a metabolic circulation whereby actors, actants and water enrol each other to coproduce their discourse and action (Swyngedouw, 2015). Such research paid little attention to native people's interactions with water because it tended to follow an orthodox marxist framework which considers that their interactions with water are necessarily doomed. This framework posits a development of history whereby Capital unavoidably disempowers small, native peasants. The interactions with water that were considered important in this literature were those involving the state and private companies (Castro, 2008). It focused on urban areas and the plight of the urban poor (Kaika, 2003) (Gandy, 2008). This theoretical framework leads this research to consider appropriation of water bodies rather than to consider the successive users interacting along a multiplicity of water flows. 
Whether it explores the conflicts concerning dam construction (Espeland, 1998), hydro-justice (Boelens, 2015) or water privatisation (Bakker, 2005), research in the political ecology of water emphasises the discursive constructions of the actors when considering water. Part of this literature has explored the water rights of native people and legal pluralism. It has explored issues of environmental justice and the difficulties involved in integrating the grass-root water law elaborated by native people into national legislation. However, it has paid surprisingly little attention to the actual, material flow of water itself unless large scale projects such as inter river transfers were considered.

Barnes (2012) and Brooks \& al (2013) pioneered a flow approach where the various actors interacting successively with the same flow of water were studied in spite of the fact each of these actors acted over a different scalar level. Lankford (2013) developed a reflection on water efficiency that also took the multiplicity of actual water flows in consideration. Trottier \& Perrier (2017) harnessed his theoretical framework to examine actual flows of water. This article proposes to focus on the myriad trajectories of water flows in the West Bank, and the manner they have been affected by this massive donor intervention, to understand the territorial transformation that has occurred. A scientific discourse relies on the silence of its object (Foucault, 1969). Examining the multiple manners water flows have been altered sheds some light on the transformation of the hydro-social cycle in a manner that is independent from the discourses of those that brought it about.

The article starts by discussing the type of impacts water projects have on trajectories of water. It distinguishes spatial, institutional and sectoral trajectories and demonstrates that the usual considerations of annual stocks of water fail to shed light on many transformations entailed by development projects concerning water. The article then details our methodology to analyse the great number of projects concerning water 
carried out thanks to donors in the West Bank since 1994. In a third section, the article discusses the changes brought overall to each type of water trajectories and their consequences on Palestinian society. It concludes with a consideration of the territorial change that these projects induced. Clearly, the overall impact of all donor supported water projects is more than the sum total of these individual projects.

When space or a resource in this space is appropriated by a social actor, it becomes a territory. The objective of this article is to understand the territorial change entailed by the interactions between donors and the PA regarding water development. It proposes a methodology to explore the manner a great number of projects may entail territorial change because they alter societal interactions with water flows. Such a methodology can be useful to understand territorial change in any situation, elsewhere in the world, where a great number of water projects are carried out by the state, with or without close interaction with donors.

This study in no way denies the fact that Israel still occupies and still abstracts water from wells located in the West Bank. The article does not study such Israeli activity, which has been the focus of most articles on Palestinian water development. The overwhelming attention paid to the role of Israel, as an occupying power, in shaping water development in the West Bank has led to a prolific literature discussed in the following section. This corpus stops short of exploring the internal Palestinian political processes that also contribute to the present water situation. Palestinians have been mostly portrayed as objects of Israeli action. Indeed, their degree of freedom is extremely limited. But they remain social and political actors. The PA and the donors use their degree of freedom and so do other Palestinian actors, such as farmers or business leaders. Our focus is to explore how Palestinian led, donor supported water projects have transformed Palestinian societal interactions concerning water. Such intraPalestinian mechanisms are important. Their interactions with donors are significant. 
The reality of Israeli occupation should not deter researchers from studying such Palestinian political developments.

\section{The Impact of Water Projects on Trajectories of Water}

Research has long portrayed water in Palestinian Territories as a competition between Israel and the PA for quantities of water. Brooks \& al (2013) showed this literature has focused on the yearly recharge of the aquifers as if it was a pie that needed to be divided between two parties. Research has emphasised the unequal distribution of water among the two populations (Frederiksen, 2003) (Zeitoun, 2008). This matches the approach of the Oslo agreements (1995) that proceeded with a quantitative allocation of water for Israel and the PA from each of the three main aquifers lying in the West Bank detailed in Annex 10, Paragraph 20, Article 40 of the Protocol Concerning Civil Affairs. This focus on 'national' quantities has obfuscated many aspects of water politics among Palestinian actors.

Recent research explored the impact of the flow reversal entailed by the largescale desalination undertaken by Israel since the 2000s. Water used to flow from the land to the sea. This has now been largely reversed in Israel. Some explored the changes this entails for power relations within Israel and at the international level (Feitelson \& Rosenthal, 2012). However, the manner water flows within Palestinian territories involve power relations among Palestinian and foreign actors has hardly been studied.

Analysing water as a complex series of flows rather than as national stocks sheds light on stakes and power relations that remain otherwise undetected. When water flows, it follows a trajectory. Interacting with this flow, such as happens within a water development project, usually alters this trajectory. Several actors located on the previous trajectory may find themselves dispossessed from all or part of the water they used to access. Elsewhere, the degradation of water quality makes former uses 
impossible once this alteration is carried out. Often, new actors, previously unrelated to water uses, benefit from the new trajectory.

The trajectories water follows may be

- Spatial, because water flows through space,

- Institutional, as water flows successively through different human institutions managing it from the moment it emerges from the earth, or from the desalinating plant, to the point where it evaporates, is transpired by a plant or an animal, or reaches the sea,

- Sectoral, as water is used successively by different sectors of activity such as agriculture, domestic use or industrial use.

Each of these three types of trajectories needs to be examined in turn.

Spatial trajectories of water flows refer to the paths water travels through whether as surface flow or underground. The Jordan River is no longer accessible to Palestinian farmers who used to divert its flow for irrigation before 1967, when the Israeli occupation began. So, for the purpose of this research on the West Bank, the only surface flows considered are springs. Their trajectory can change naturally. For instance, sudden floods may cause reflux phenomena underground that lead a spring to disappear. The trajectory and the flow of springs can also be altered artificially. For instance, wastewater released in the environment can swell the water of a naturally flowing spring. Underground flows are inextricably linked to surface flows. The karstic soil of the West Bank means that the complex trajectories of water underground are extremely difficult to map or model. Underground water trajectories can change naturally, such as in the example of refluxes cited above. They can also be altered artificially. For instance, the wells in Kufr Adam, close to Jenin, stopped being dry since the treated wastewater reuse scheme was put in place. This scheme brings treated wastewater from Jenin's treatment plant to irrigate fields and orchards. Enough water percolated from this irrigation to replenish these wells, an inadvertent result of the reuse 
scheme.

Infrastructure can transform spatial trajectories of water radically. For example, Los Angeles redirected the Owen River through several hundred kilometres to reach its drinking water network. (Reisner, 1993) Elsewhere, the Amu Darya and Sy Daria rivers were redirected by the Soviet Union to cotton fields for irrigation, thus causing the disappearance of the Aral Sea (Karimov, Lieth, Kurambaeva, \& Matsapaeva, 2005). On a smaller scale, when treated wastewater is directed towards irrigation, this reuse is usually depicted as a 'creation of a new resource' (Alfarra, Kemp-Benedict, Hötzl, Sader, \& Sonneveld, 2011). This is inaccurate. Reuse of treated wastewater in irrigation results from deviating water from a previous trajectory into a new trajectory. Considering spatial trajectories of water, before and after projects are carried out, allows discerning the impacts of their alteration on the actors interacting with these flows and on the uses they made of this water.

Currently, spatial trajectories of water in the West Bank are mapped very roughly, over a large scale. Three main aquifers lie under the West Bank. The most plentiful flows towards the west, into Israel. The northeastern aquifer flows northward into Israel and the eastern aquifer flows mostly towards the Jordan River as illustrated by Map 1 . 


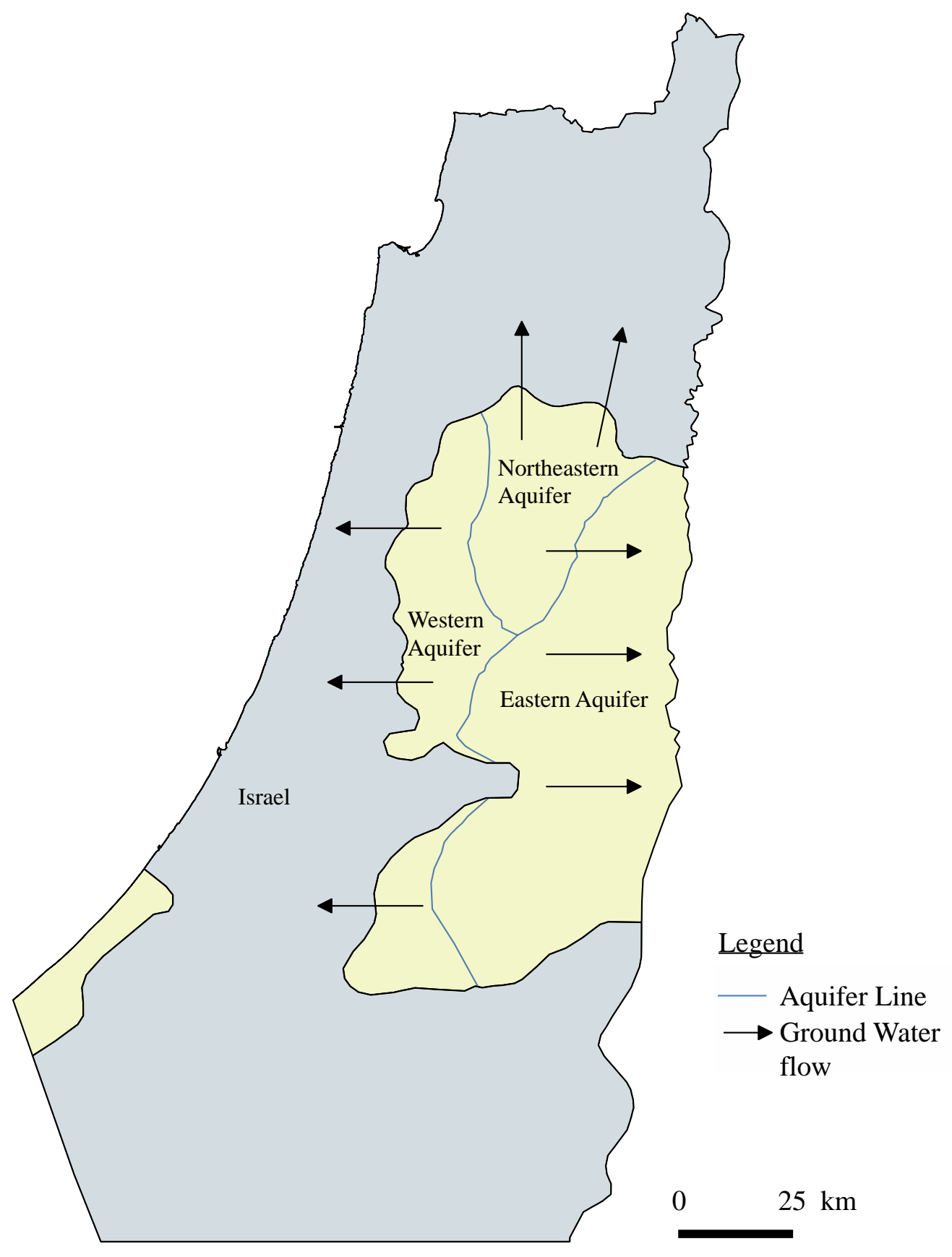

Source : authors

Map 1 - The three aquifers and their drainage zones in the West Bank

Israel has built a series of wastewater treatment plants (WWTPs), inside Israel, along the Green Line, to treat the wastewater reaching it as surface flow from the West Bank through six entry points (see Map 2). Maps 2, 3 and 4 locate all information within the zoning of the West Bank into $\mathrm{A}, \mathrm{B}$ and $\mathrm{C}$ areas. For a discussion of these areas, see appendix 1. 


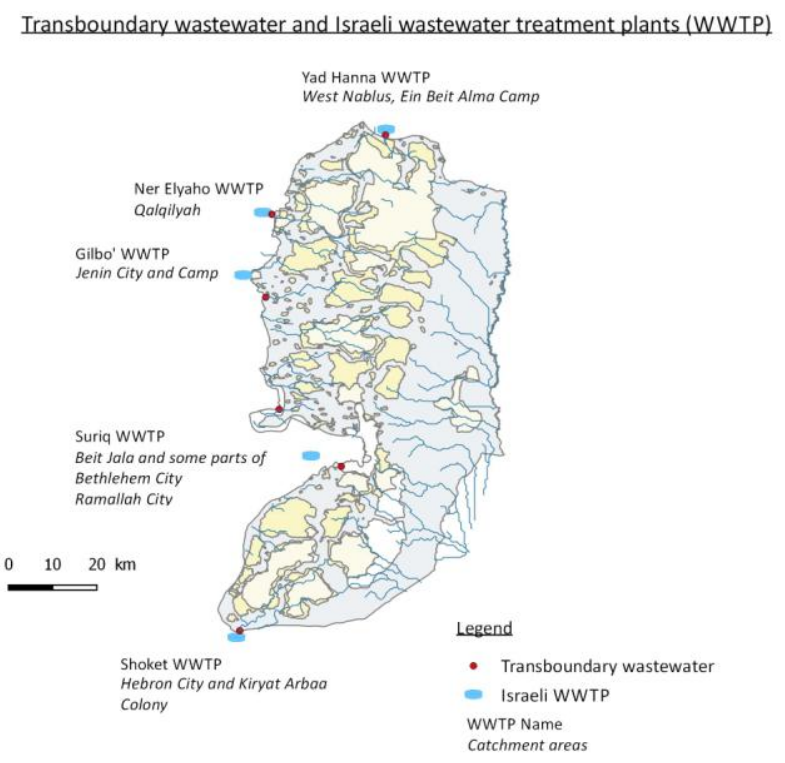

Map 2 - Transboundary wastewater and Israeli wastewater treatment plants Israel charges the PA both for the building costs and the running costs of these plants. It then supplies the outcoming treated wastewater to Israeli farmers inside Israel (Fischendler, 2011). This Israeli policy largely drives the present Palestinian reuse projects as discussed in the third section of this article. This large-scale depiction of spatial flows of water doesn't account for the many changes that occurred in recent years. Ein Far'a spring has dried out (Tomeizeh \& Naslund, 2006). So did Ein Shibli, Ein Mishka and Ein Auja springs. All flowed abundantly until numerous, mostly unlicenced, wells started being drilled after 1994. These wells redirected the spatial trajectories of water. This caused the springs to dry. Elsewhere, new surface streams became perennial as cities and villages increasingly generated untreated wastewater. These new trajectories of surface and groundwater have yet to be mapped. The changes in these trajectories have had a huge impact on Palestinian's interactions with water.

Institutional trajectories of water refer to the course of water through different forms of management from the moment it emerges either from the ground, or from the desalination plant, up to the point it evaporates or is transpired by a plant or an animal as illustrated in Figure 1. 


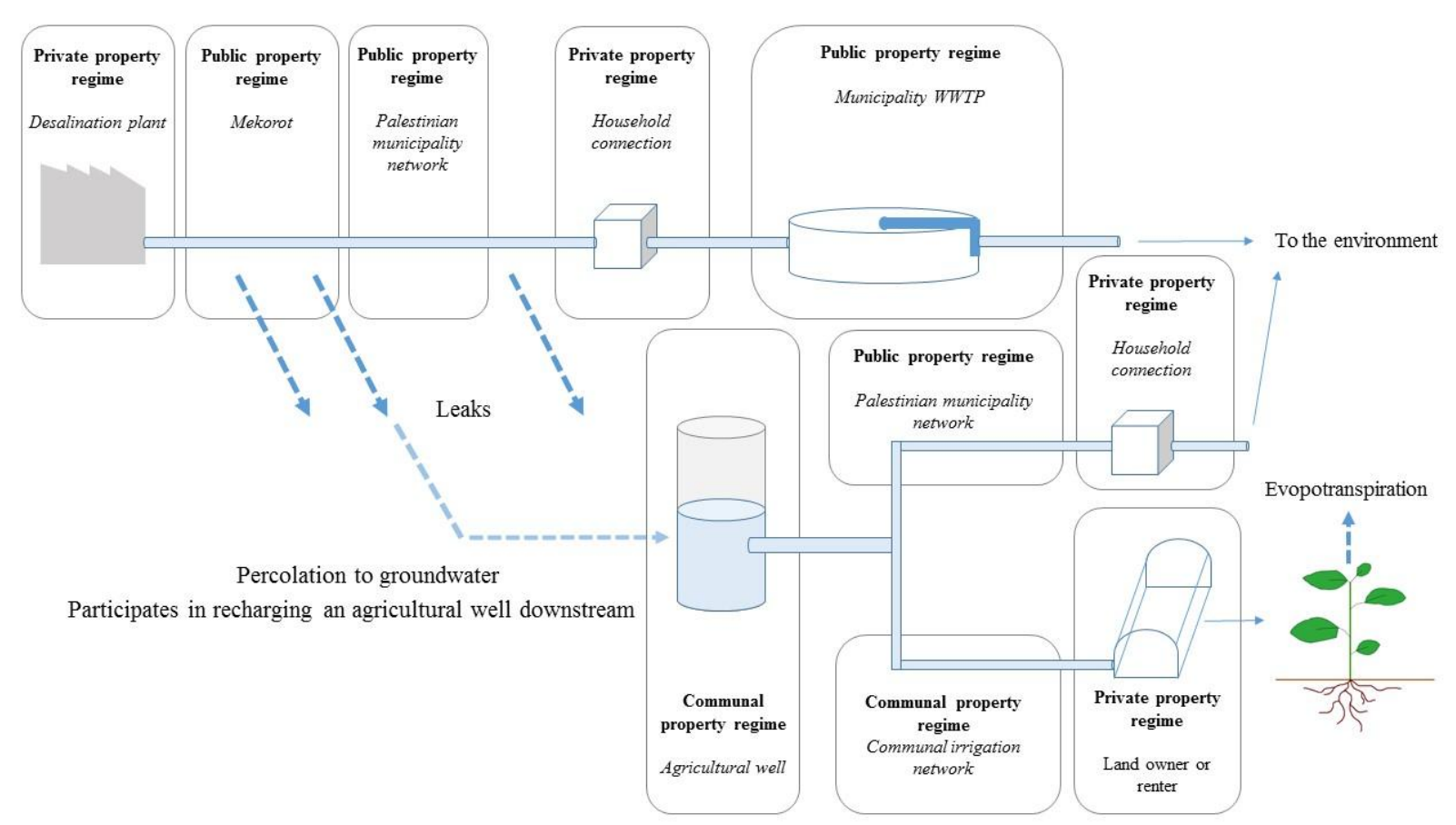

Figure 1 - Example of institutional trajectories of water flows

Understanding institutional trajectories requires us to understand water tenure.

Tenure designates the relationship, either legally or customarily defined, between people, as individuals or groups, with respect to a resource (Hodgson, 2016). Tenure is a social construction. It can be formal or informal, individual or collective. In the West Bank, when spring water is directed to a field, it is usually managed by farmers according to a common property regime. When a portion of this water seeps into the ground and recharges a well, it becomes managed by another institution. If the well is an agricultural well, the water might now be managed by a "shirket al bir", literally a 'well company' in dialectal Arabic. Such an institution is made up of farmers and deploys a common property regime over the water and the well, which is described in written statutes. The well might also be privately owned, in which case a private property regime now applies to the water. Once this water is abstracted from that well and directed to a field or an orchard, it may seep again into the ground and reappear in a well that is managed either by Israel or by the Palestinian Water Authority (PWA). In this case, it becomes managed by a public property regime (Trottier \& Perrier, 2017). Considering institutional trajectories allows understanding how various forms of water tenure are embedded within each other. It also allows understanding which forms of 
social organisation destined to manage water are strengthened or undermined whenever spatial trajectories are altered.

Sectoral trajectories refer to the course of water, as it is used successively in different sectors such as domestic use, industrial use or agriculture. Most domestic water is not consumed when it is used. Water becomes consumed when it evaporates, when it is transpired by an animal or a plant, or when it reaches the sea. The water that flows out of a household, after a bath for example, has been used but has not been consumed. Considering sectoral trajectories of water allows understanding the overall impact resulting from changes in either spatial or institutional trajectories. For instance, a project that refurbishes a reticulation network eliminates many of the leaks along this network. This changes the spatial trajectory of water because the flow of this leaked water to neighboring agricultural wells is decreased. It also changes the institutional trajectory. The flow of water through a farmer managed common property regime used for the well is reduced while the flow of water through a WWTP according to a public property regime is increased. Finally, the sectoral trajectory of this water is also altered if the water from the leaks that previously flowed to the farmer managed well was previously used in irrigation while the WWTP sells its treated wastewater to an industry, for instance. In this case, a change in spatial trajectory occasioned an institutional change from a common property regime to a public property regime and a sectoral change from irrigation to industry.

These three types of trajectories are subsets of each other. Spatial trajectories don’t necessarily entail institutional trajectories. For instance, water in a river flowing through a desert island follows a spatial trajectory but doesn't follow an institutional or a sectoral trajectory. But institutional trajectories necessarily entail a spatial trajectory. And sectoral trajectories necessarily entail an institutional trajectory. Changes in these three types of trajectories, taken all together, effectuate territorial transformation. This is examined in the last part of this article. 
Since 1994, over 2000 projects concerning water were proposed for donor funding in the West Bank. Almost half of them were actually funded and $90 \%$ of the funded projects were implemented or ongoing in 2016. These projects were systematically planned and implemented in a piecemeal fashion, with consideration of their impact only in a very limited manner and over a small scale. The West Bank is a small place: 5,655 $\mathrm{km}^{2}$ (OCHA, 2015). Research has also long shown the large sums that donors have invested in water development projects in the West Bank (Le More, 2008). So many water projects in such a small area have massively impacted spatial, institutional and sectoral water trajectories. The manner this impacts territorial transformation has yet to be studied. Yet, research has long demonstrated that a piecemeal approach to development projects can have huge, overall, unwanted negative effects on a country (Ferguson, 1990). Uvin (1998) demonstrated, for instance, the manner the many development projects in Rwanda contributed unintentionally to conditions that brought about the 1994 genocide. The overall impact of all donor supported water projects is more than the sum total of these projects. Understanding this overall impact requires us to understand how these projects alter the many trajectories of water and thus how they alter the manner Palestinian society structures its interactions with water. This allows understanding the path dependency and the territorial transformation entailed by this massive aid concerning water that poured into the West Bank since 1994.

\section{Methodology}

Our methodology combined several years of extensive fieldwork, deploying qualitative research methods, with quantitative methods and geographical information system analysis. We used three databases of water projects that were proposed by the PA for donor funding. Two of these databases had been compiled by the PWA, one in 2016, showing 1978 projects (Palestinian Water Authority, 2016) and one in 2009 listing 1135 projects (Palestinian Water Authority, 2009). One was compiled by the World Bank in 
2009, listing 200 projects (World Bank, 2009). These three databases overlapped in part as some projects appeared in several bases. Moreover, large projects sometimes appeared as a series of distinct slices, each of which might be funded by a different donor or by the same donor but over different periods of time.

These databases were elaborated for political reasons. Espeland (1998) noted that numbers are the tools of the weak when they face powerful outsiders. The West Bank water databases are no exception. The 2009 databases were gathered to support the "Palestinian Reform and Development plan" led by Prime Minister Fayyad starting in 2007. State institutions always have political objectives when they gather data. Databases may still prove useful to researchers providing they are used carefully. All databases distinguished between « inactive » projects that had not yet received either a permit from the Joint Water Committee (JWC) or a commitment from a donor, from « active » projects where donors had pledged funding but may not yet be undertaken. For a project to exist in these databases, someone, usually a donor, had to fund drafting the proposal. As a result, the projects are simultaneously Palestinian led and donor driven as well as donor supported. So, we studied all the projects, whether ongoing or unfunded. Indeed, these projects reflect the vision donors have for Palestinian water.

The maps, graphs and tables this study produces on the basis of these databases specify systematically whether they illustrate (1) both funded and unfunded projects or (2) only funded projects. Projects that were neither funded nor implemented could not effectuate territorial transformation. Nevertheless, they are also worth being studied because their not being funded testifies to a development that wasn't pursued by donors. Their being funded but not implemented testifies to a development that was pursued by donors but met with resistance from either Palestinian or Israeli actors.

The PWA databases were gathered in order to provide an overview of all water projects in the West Bank. The World Bank's database was part of its Movement and 
Access study series. It sought to allow a balanced analysis and create awareness of the factors restricting Palestinian water sector development. Table 1 summarises the type of information each database provided.

Table 1. Information on the three databases

\begin{tabular}{|c|c|c|}
\hline & Number of projects & $\begin{array}{l}\text { Information about the } \\
\text { projects provided }\end{array}$ \\
\hline PWA database of 2009 & 1135 & $\begin{array}{l}\text { Short description of project } \\
\text { Donor (if funded) } \\
\text { Implementing agency (if active) } \\
\text { Location of project } \\
\text { Distinguishes between } \\
\text { proposed or active projects } \\
\text { Costs (if project is active) }\end{array}$ \\
\hline PWA database of 2016 & 1978 & $\begin{array}{l}\text { Short description of project } \\
\text { Donor (if funded) } \\
\text { Implementing agency (if active) } \\
\text { Location of project } \\
\text { Year of proposal } \\
\text { Distinguishes between } \\
\text { unfunded or submitted or } \\
\text { implemented or ongoing } \\
\text { Costs (if project is active) } \\
\end{array}$ \\
\hline World Bank database 2009 & 200 & $\begin{array}{l}\text { Short description of project } \\
\text { Donor (if funded) } \\
\text { Location of project } \\
\text { Estimated Cost } \\
\text { Planned number of } \\
\text { beneficiaries of projects } \\
\text { Date of submittal to JWC } \\
\text { Date of approval of JWC } \\
\text { Distinguishes between pending } \\
\text { approval or approved by JWC }\end{array}$ \\
\hline
\end{tabular}

The information provided in these databases was combined with results from fieldwork on these projects' interactions with water trajectories carried out from 2016 
through 2018 in the West Bank. This included field observations such as visits to farmers, their lands and their wells, semi-structured interviews and participant observation in meetings involving donors, the PWA and local contractors. This allowed identifying some inaccuracies in the databases, which are discussed at the end of appendix 2. A detailed description of our methodology appears in appendix 1. The information was spatialized to understand which transformations predominated over which areas of the West Bank.

Wastewater treatment projects and projects of reuse of treated wastewater required specific attention. They emerged as the type of projects that interacts with the biggest flows overall. They also redirect the spatial, institutional and sectoral trajectories of water flows far more than the other types of projects. A detailed description of our methodology to assess wastewater treatment and reuse projects appears in appendix 2.

The shortcomings of this methodology are discussed at the end of appendix 2. Nevertheless, this methodology had some usefulness. Using this data cannot provide absolute values in terms of quantities and flows. This methodology allows identifying trends whereby spatial, institutional and sectoral flows are altered. This allows us to understand which categories of actors previously interacting with a water flow are dispossessed and which categories of actors that were not previously interacting with a water flow now start doing so. In so doing, we understand the transformations of societal interactions concerning water brought about by donors, whether these were intentional or not.

\section{The Changes in Water Trajectories Emerging from 25 years of Donor Supported Water Development}

Donors funded, in part, the type of projects Israel had been developing in the West Bank, in the sector of domestic water, after its occupation in 1967. They also funded irrigation water and wastewater projects, a type of project initially introduced 
during the first intifada by Palestinian non-governmental organisations (NGOs) such as the Palestinian Agricultural Relief Committees (PARC) or the Union of Agricultural Work Committee (UAWC). Donor intervention increased the dimensions and number of such projects significantly after 1994. Table 2 shows the number of each type of projects that appear in the databases. Figure 2 shows the number of projects along a timeline according to the year they were proposed. The number grew up till the outbreak of the second intifada at the end of 2000. It then decreased to a low in 2007 before reaching a peak in 2010. This matches the local historical landmarks. During the intifada (2000-2004), the security situation prevented the emergence of new projects. The 2006 elections led Hamas to victory, which did not please donors. The latter threw their support behind the government of Salam Fayyad who became prime minister in 2007. Elaborating a water project takes time and the 2010 peak corresponds to the lag time between the advent of the Fayyad government and the completion of the proposals. 
Table 2. Number of domestic, agricultural water and wastewater projects according to the different databases.

\begin{tabular}{|c|c|c|c|c|c|}
\cline { 2 - 6 } \multicolumn{1}{c|}{} & \multicolumn{5}{c|}{ Number of projects } \\
\hline Database & Domestic water projects & Agricultural water & Wastewater & Others & TOTAL \\
\hline PWA 2016 & 1378 & 197 & 222 & 181 & 1978 \\
\hline PWA 2009 & 553 & 4 & 468 & 110 & 1135 \\
\hline $\begin{array}{c}\text { World Bank } \\
\text { 2010 }\end{array}$ & 175 & 12 & 13 & 0 & 200 \\
\hline
\end{tabular}


Figure 2

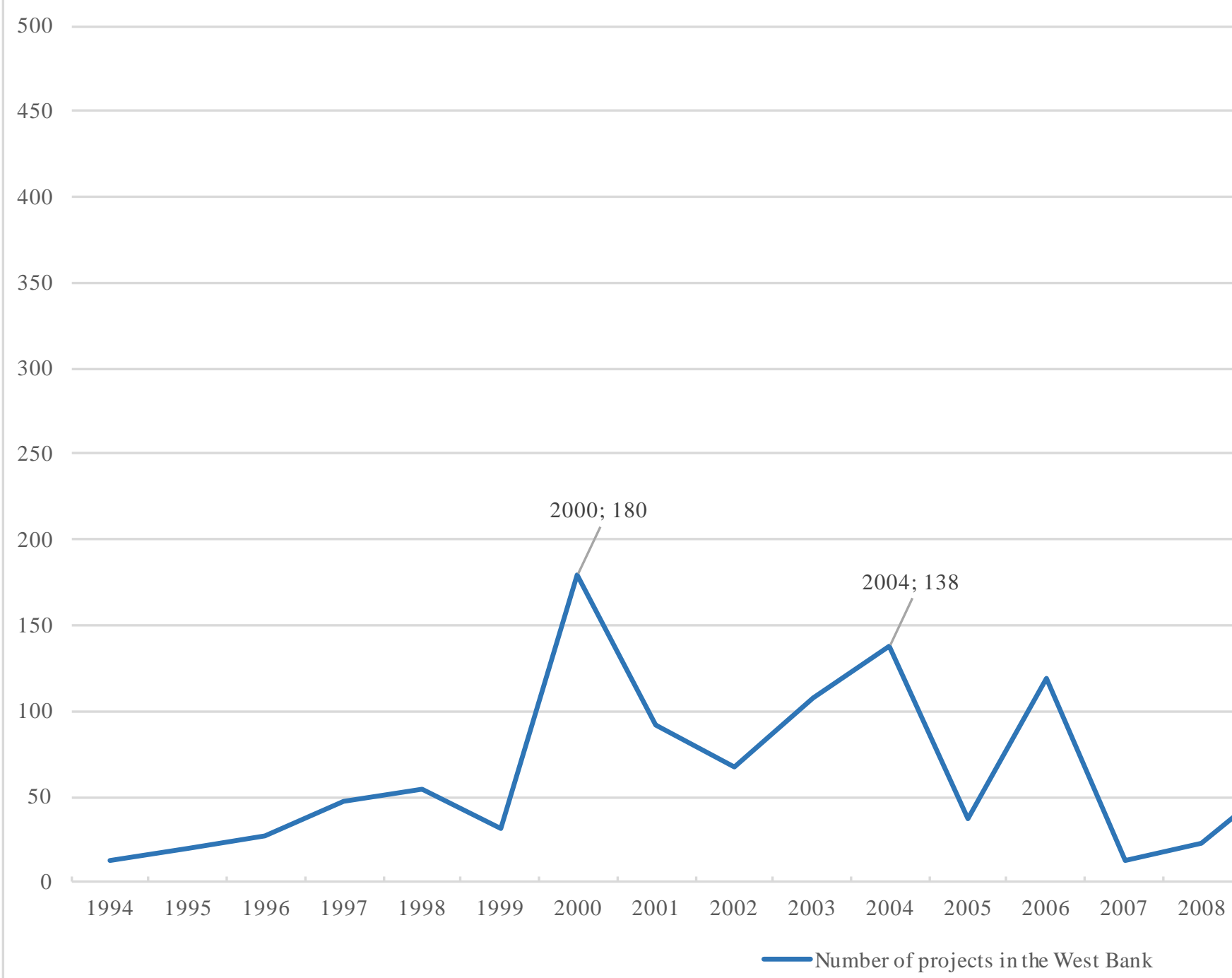

Figure 2: Number of water projects according to the year they were proposed from 1994 to 2016 (PWA, 2016)

\section{Changes in spatial trajectories of water}

Domestic water projects are the most ancient and most numerous projects (see Figure 3

(a)(b)(c) and Table 2). 
Figure 3 (a)

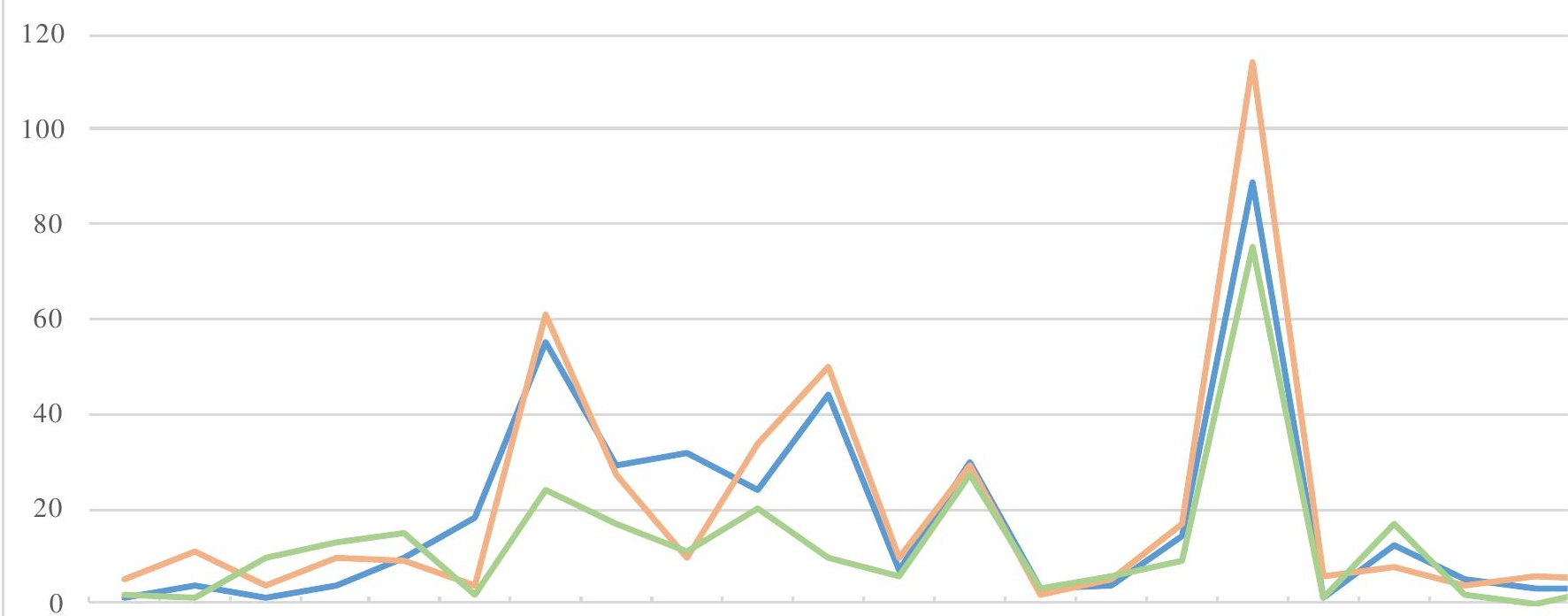

199419951996199719981999200020012002200320042005200620072008200920102011201220132014 $\longrightarrow$ Eastern Aquifer $\longrightarrow$ Western Aquifer $\quad$ Northeastern Aquifer

Figure 3 (b)

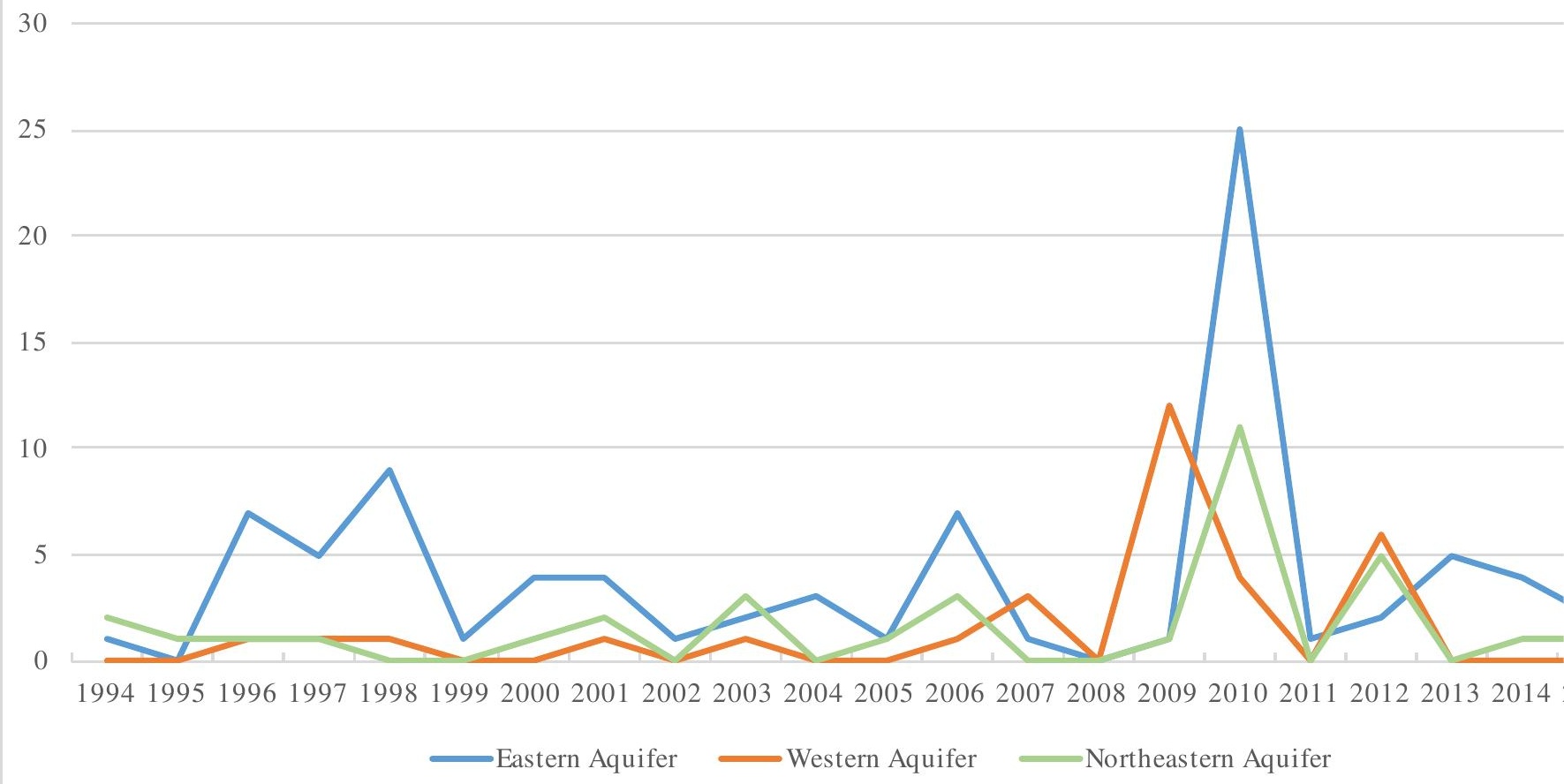

Figure 3 (c)

30

25

20

15

10

Eastern Aquifer $\quad$ Western Aquifer $\quad$ Northeastern Aquifer

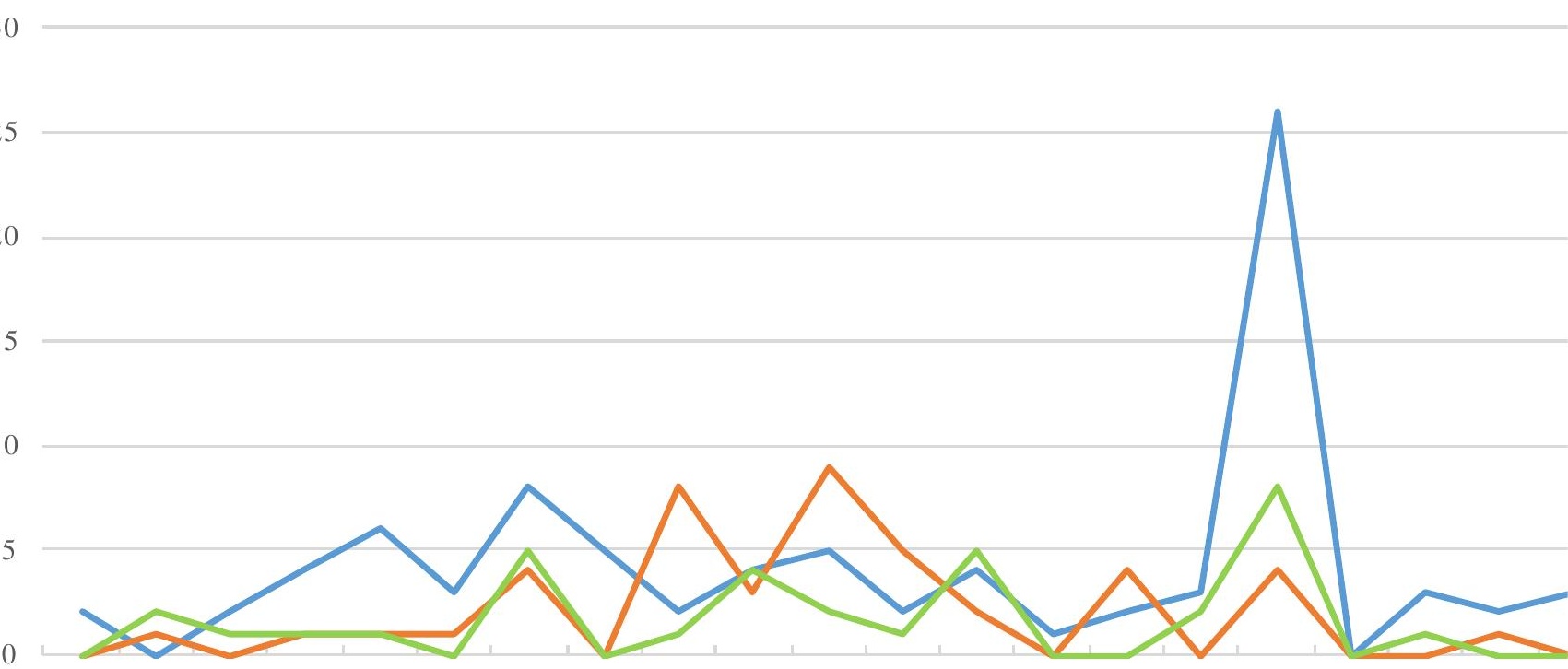


Figure 3 (a) Number of domestic water projects for each aquifer, 1994-2016 (b)

Number of agricultural water projects for each aquifer, 1994-2016 (c) Number of wastewater projects for each aquifer, 1994-2016. All data from PWA (2016)

These projects included the construction, rehabilitation or extension of domestic water networks, well drilling and rainwater harvesting. Between 1994 and 2016, 43\% of domestic water projects that were proposed were funded (see Table 3). The construction and rehabilitation of domestic water networks made up $73 \%$ of the projects that obtained funding. With 593 funded projects, domestic water projects were the type most implemented. Map 3 shows most were located over the western aquifer. This matches the pre-existing demographic distribution and contributed to its perpetuation.

Table 3.Type and proportion of funded and undunded domestic, agricultural water and wastewater projects (PWA 2016)

\begin{tabular}{|c|c|c|c|c|c|c|}
\hline & $\begin{array}{l}\text { Number of } \\
\text { projects }\end{array}$ & $\begin{array}{l}\text { Proportion of } \\
\text { funded projects }\end{array}$ & Funded projects & $\begin{array}{l}\text { Proportion of } \\
\text { the funded } \\
\text { projects }\end{array}$ & Unfunded projects & $\begin{array}{l}\text { Proportion of } \\
\text { unfunded projects }\end{array}$ \\
\hline \multirow{2}{*}{$\begin{array}{l}\text { Domestic water } \\
\text { projects }\end{array}$} & \multirow{2}{*}{1378} & \multirow{2}{*}{$43 \%$} & $\begin{array}{c}\text { Construction of domestic water } \\
\text { network }\end{array}$ & $45 \%$ & $\begin{array}{l}\text { Construction and } \\
\text { rehabilitation of } \\
\text { domestic water } \\
\text { networks }\end{array}$ & $70 \%$ \\
\hline & & & $\begin{array}{l}\text { Rehabilitation of domestic } \\
\text { water network }\end{array}$ & $28 \%$ & Rainwater harvesting & $19 \%$ \\
\hline \multirow[b]{2}{*}{$\begin{array}{l}\text { Agricultural } \\
\text { water projects }\end{array}$} & \multirow[b]{2}{*}{197} & \multirow[b]{2}{*}{$33 \%$} & Storm Water sewerage & $42 \%$ & \multirow[b]{2}{*}{$\begin{array}{l}\text { Wastewater reuse in } \\
\text { agriculture }\end{array}$} & \multirow[b]{2}{*}{$64 \%$} \\
\hline & & & $\begin{array}{l}\text { Irrigation network rehabilitation } \\
\text { / improvement }\end{array}$ & $26 \%$ & & \\
\hline \multirow{2}{*}{$\begin{array}{l}\text { Wastewater } \\
\text { projects }\end{array}$} & \multirow[b]{2}{*}{222} & \multirow[b]{2}{*}{$50 \%$} & $\begin{array}{l}\text { Construction and rehabilitation } \\
\text { of wastewater network }\end{array}$ & $74 \%$ & $\begin{array}{c}\text { Construction of } \\
\text { wastewater network }\end{array}$ & $56 \%$ \\
\hline & & & $\begin{array}{l}\text { Construction of wastewater } \\
\text { treatment plant }\end{array}$ & $10 \%$ & $\begin{array}{c}\text { Construction of } \\
\text { wastewater treatment } \\
\text { plant }\end{array}$ & $19 \%$ \\
\hline
\end{tabular}




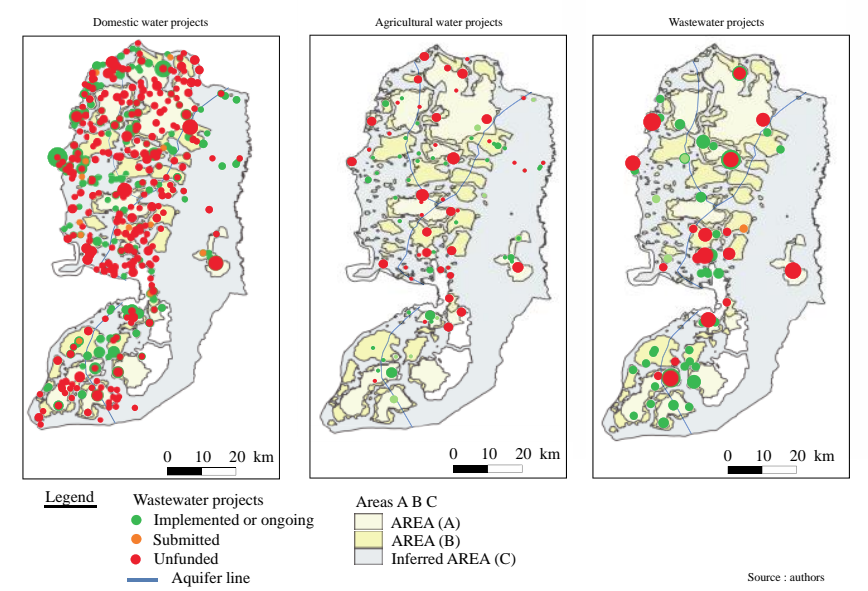

Map 3. Status of the water projects in the West Bank from 1994 to 2016 (PWA 2016)

The construction or extension of domestic water network or the drilling of a well creates a new spatial trajectory for water. The new, donor funded wells drilled in the West Bank reached depths over 600 meters. They tapped the lower, confined aquifer, a novelty for Palestinians whose wells, up to 1994, had mostly tapped the upper, unconfined aquifer.

The rehabilitation of domestic water networks changes the proportion of flows along two different trajectories. More water flows to the designated destination and less water leaks out of the reticulation network. Consequently, the leaked flow along the trajectory leading water to the neighboring wells tapping into the unconfined aquifer, or to neighboring fields decreases. A brand new, or newly rehabilitated reticulation network typically leaks $20 \%$ of its water. Older, badly maintained networks could leak 
$50 \%$ or more of the water they carried. The difference in the flow to the neighboring unconfined aquifer is significant. Rainwater harvesting projects least altered the spatial trajectory of water. They mostly delayed the percolation of rainwater through the soil because they tended to occur where houses were unconnected to a sewage system. However, $88 \%$ of rainwater harvesting projects appearing in the databases were never funded.

The significant development of domestic networks contributed to an increasing dependence of the PWA upon Mekorot. By 2011, the PWA purchased 53 million $\mathrm{m}^{3} /$ year from the Israeli national water company, Mekorot (Palestinian Water Authority, 2011). Overall, that year, its domestic networks received 88.3 million $\mathrm{m}^{3} /$ year and « consumed » [sic] 62.3 million $\mathrm{m}^{3} /$ year. Already, $60 \%$ of domestic water managed by the PWA was purchased from Israel. In 2016, the PWA purchased 69 million $\mathrm{m}^{3}$ from Mekorot, i.e. $59 \%$ of the 117 million $\mathrm{m}^{3}$ it was directing to domestic networks (World Bank Group, 2018). Mekorot uses a variety of sources, including wells located in Israel as well as in the West Bank, but the large-scale desalination Israel undertook in the 2000s has led to a steady increase in the share of desalinated water within the portion of water it supplies to the PWA.

Overall, three trends emerged concerning the impacts of domestic water projects on spatial trajectories of water since 1994:

(1) They decreased the flow of water travelling towards the unconfined aquifer close to the networks.

(2) They increased a flow of desalinated water traveling from the coast to populated areas of the West Bank.

(3) They increased a flow of wastewater leaving the inhabitations and returning to the environment whether treated or untreated.

Agricultural water projects were least favored by donors (see Figure 3 (a)(b)(c) and Table 2 and 3). Even including treated wastewater reuse projects, only 197 
agricultural water projects were proposed, of which only $33 \%$ were funded. These projects included irrigation network rehabilitation or improvement that accounted for $26 \%$ of the funded projects. They also included storm water sewerage projects which accounted for $42 \%$ of the funded projects. More recently, they also included wastewater reuse. Rehabilitation projects may transform open-air irrigation systems into piped systems. They may consist of lining dirt irrigation channels with cement or repairing the leaks in an existing piped system. Irrigation improvement usually means switching to drip irrigation. In each case, a greater proportion of the irrigation water flow is directed to plants to be transpired and less water percolates into the ground. This means less water flows towards uncultivated plants such as khubbeza, a highly nutritious weed which people pick free of charge in cultivated fields. Such weeds constitute a staple food for the poor (Trottier \& Perrier, 2017). Less water percolating through the soil means less water recharging the unconfined aquifer and percolating towards the neighboring village's well.

As of 2016, agricultural water projects, both proposed and funded, have been mostly located in the eastern aquifer (see Figure 3 (b), Table 4 and Map 3). The eastern aquifer hosts the highest number and the highest proportion of proposed agricultural projects. 


\begin{tabular}{|c|c|c|}
\hline Aquifer & $\begin{array}{c}\text { Number of } \\
\text { projects }\end{array}$ & $\begin{array}{c}\text { Number of total } \\
\text { water projects } \\
\text { (when known) }\end{array}$ \\
\hline Western & 51 & 785 \\
\hline Northeastern & 42 & 441 \\
\hline Eastern & 103 & 685 \\
\hline
\end{tabular}

Palestinian irrigation, up to the advent of reuse projects, relied on farmer managed wells or springs - both tapping the unconfined aquifer - the water of which was channeled to neighbouring lands (Trottier \& Perrier, 2018). Before 1999, most irrigation from wells was located in the northwest of the West Bank over the western and northeastern aquifers. Most spring irrigation was located in the Jordan Valley over the eastern 
aquifer and, to a lesser extent, south of Jerusalem over the western aquifer. The springs either dried out or have seen their flows drastically reduced in recent years. Agricultural water projects tended to neglect the northwest of the West Bank. They often targeted users and land in the Jordan Valley that was not previously irrigated. Spring rehabilitation was funded in the late nineties. This is now superseded by new projects to reuse treated wastewater generated by the newly built WWTPs. Such projects are examined in the following section, dealing with wastewater.

Overall, four trends emerged concerning the impacts of agricultural water projects since 1994 on spatial trajectories of water:

(1) A greater proportion of the irrigation water is directed to cultivated plants to be transpired.

(2) A lesser proportion of the irrigation water is directed to nourishing weeds and to crops cultivated within polyculture for subsistence purposes.

(3) A lesser proportion of the irrigation water recharges the upper, unconfined aquifer that supplies neighbouring fields and the wells of neighbouring villages with water.

(4) A new flow of water is brought to previously unirrigated land.

By 2016, wastewater projects totaled 222, of which $50 \%$ were funded (see Table 3). The construction and rehabilitation of wastewater networks made up $74 \%$ of the funded projects. The construction of WWTPs made up $10 \%$ of the funded projects. WWTPs and reuse projects emerge in the early 2000s and multiply in the 2010s. The distribution of WWTPs doesn't depend only on the space available for building such large infrastructure. It also depends on land tenure, on Israeli permits from the civil administration for area $\mathrm{C}$, and on politically motivated reasons from municipalities in some cases.

Reuse projects account for $64 \%$ of the projects that remain unfunded. This high rate is logical because most of them were proposed very recently. Appendix 2 details 
our methodology to calculate the flows involved in WWTPs and reuse projects. They entail the most significant changes in spatial trajectories of water (see Table 5). This is unsurprising because WWTPs usually collect the flow generated by several reticulation networks. Table 5 shows the outflow of the existing WWTPs is already important. It shows this outflow will increase significantly in the near future. Domestic water projects had predominated in the initial years of donors' involvement. WWTPs and reuse projects now constitute the next wave of donor led water development. 
Table 5. Present and planned treated wastewater outflow and treated wastewater reuse flows for existing WWTPs and WWTPs under construction.

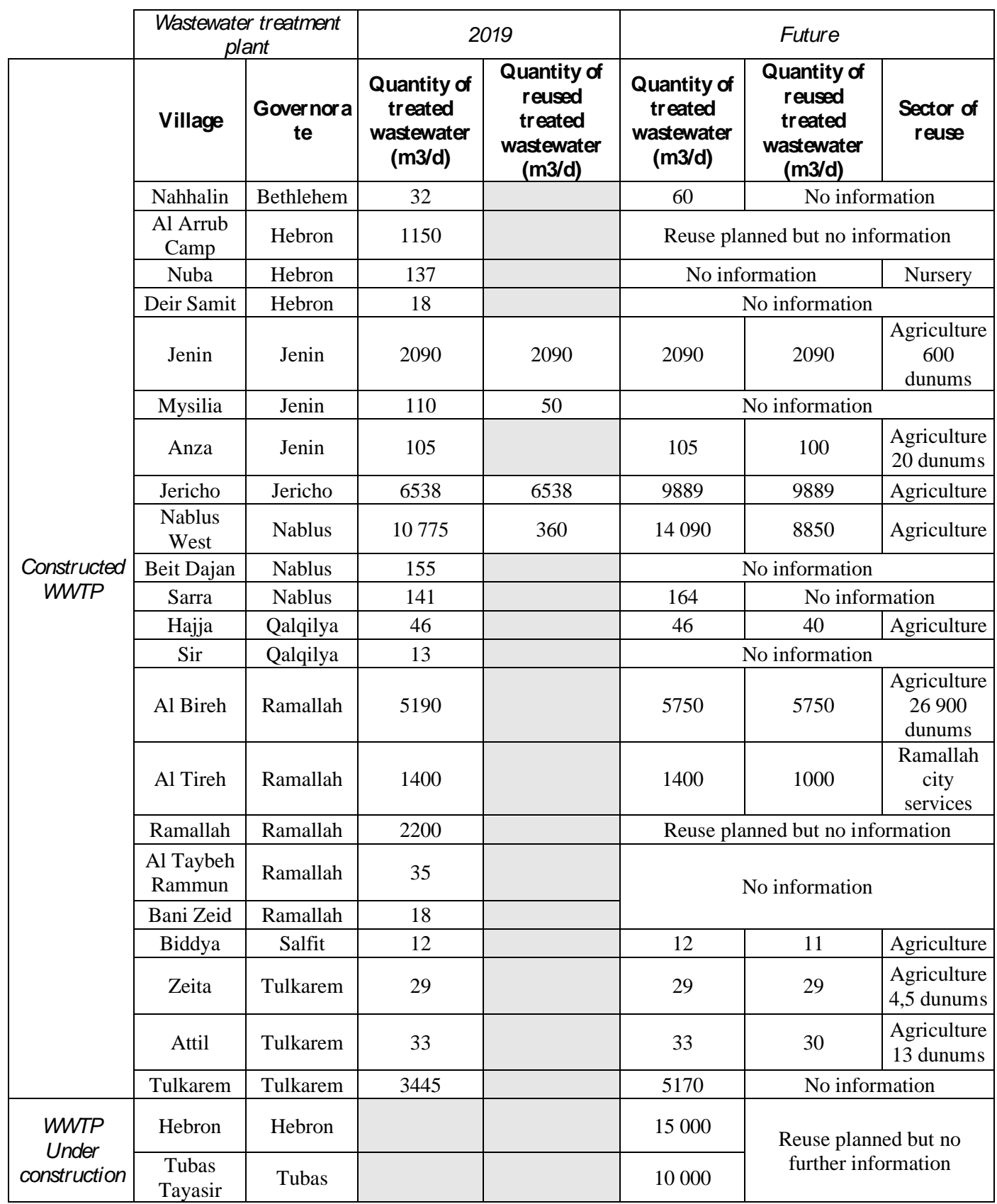

Up till donor intervention, nearly all wastewater seeped into the aquifer through domestic cesspits or was channeled into a nearby wadi, i.e. into a valley, ravine, or channel that is dry except in the rainy season. The many trajectories of these flows led simultaneously to a recharge and a contamination of the upper unconfined aquifer. The wastewater eventually gathered in wadis and, in the western and northeastern aquifer, 
flowed into Israel through the Green Line, mainly through the six entry points illustrated on Map 2. In 2017, 21.4 million $\mathrm{m}^{3}$ of wastewater flowed into Israel which billed the PA 31 million\$ for treating it (World Bank Group, 2018). The PA counts on WWTPs and reuse projects to eliminate this outflow of surface wastewater into Israel, thereby eliminating this sizeable expense.

Field work reveals that Jenin shows the most advanced case of reuse and illustrates this trend. The WWTP provides secondary treatment. Its outflow is channeled to formerly rainfed fields growing fodder north of the plant, through an underground drip irrigation system, and to orchards through an above ground drip irrigation system. Here, sheep raising enticed farmers to invest in irrigating fodder. Previously, rainfed fodder only generated one crop a year. Now, the same plot provides ten crops a year. What used to be a surface flow of wastewater into Israel has now been directed to fodder and trees for transpiration for 8 months of the year. Farmers don't irrigate for the remaining 4 months because rainfall spares them the cost of treated wastewater. During those months, the outflow of the wastewater plant keeps reaching Israel. A waiting list of farmers exists, ready to purchase any additional treated wastewater once more houses are connected to the plant. Neighbouring farmers, with water rights to local wells that are now dry, are not participating in this project.

Many wells tapping the upper unconfined aquifer in villages located between Jenin and the northern limit with Israel have become dry since 2006. Yet, as in the rest of the West Bank, no project aimed to recharge the aquifer to supply them with water once again. An unintended consequence of the reuse project in Jenin was the replenishment of wells in the neighbouring village of Kufr Adam. The reuse project directed the flow of treated wastewater in part, as planned, to plants for transpiration and, in part, unwittingly, to these agricultural wells.

Reuse projects in the West Bank aim to irrigate previously rainfed or uncultivated land. None aim to direct water to farmers who irrigated previously or to 
recharge their wells or springs. Thus, reuse projects are creating new trajectories for water. Map 4 and Table 5 illustrate these changes in spatial trajectories and the flows this represents once the reuse projects are implemented. 

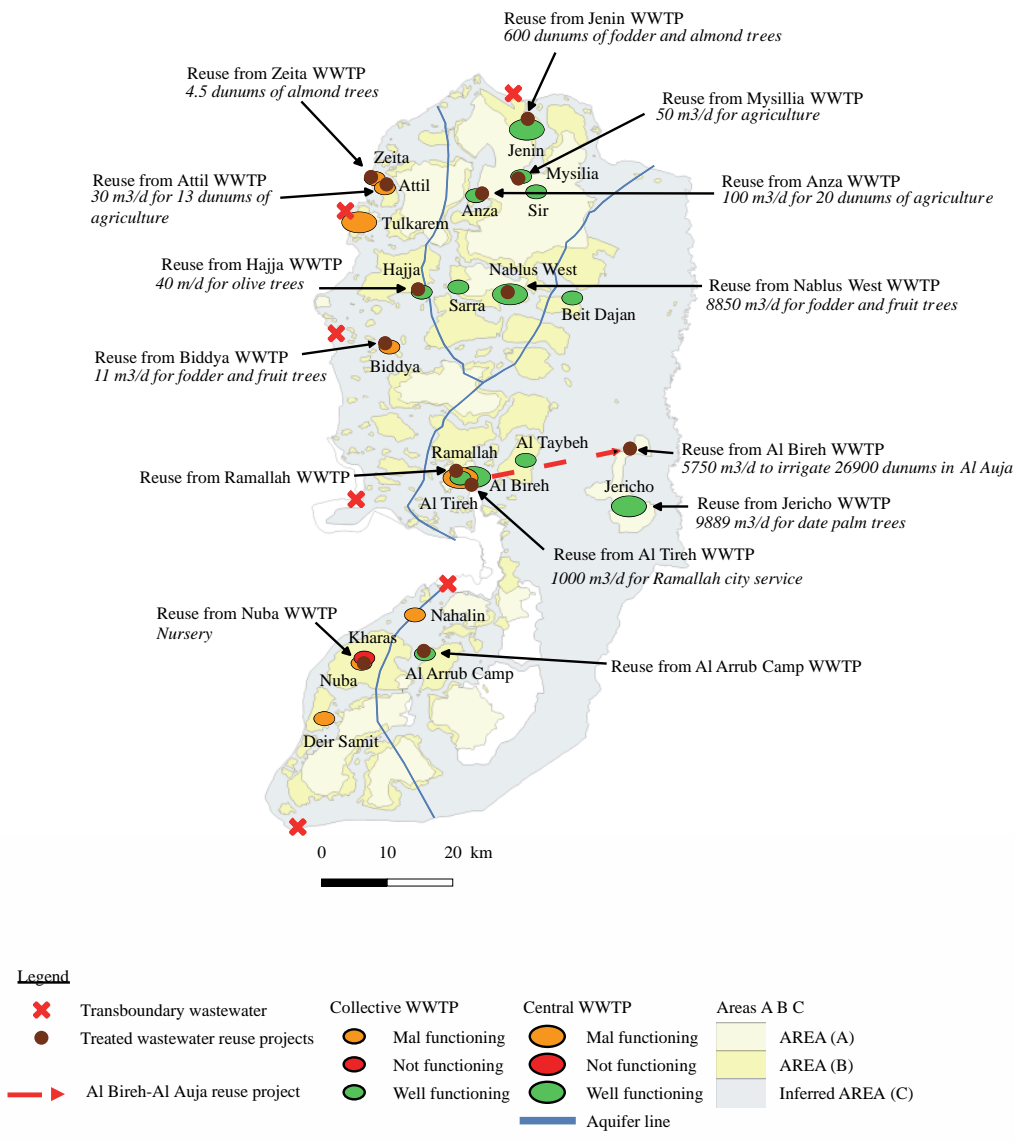
The 2016 database shows wastewater projects are mostly located in the eastern aquifer as illustrated in Figure 3 (c) and Map 3.

The 2013 PWA strategy aims to direct most of the reused water to the Jordan Valley in order to irrigate date palm trees (Palestinian Water Authority, 2013). This could entail a trunk line carrying treated wastewater from Al Bireh to Al Auja, bringing water $40 \mathrm{~km}$ away to land never previously irrigated. This project has yet to obtain funding but its feasibility study was completed thanks to European Union funding (Environmental and Social Impact Assessment for Al-Bireh Reuse Trunk Line to Al-Auja Area, 2016). Such expensive projects could be avoided if the treated wastewater was instead used to recharge the upper unconfined aquifer supplying existing agricultural wells and springs with water. Altering the spatial trajectories of wastewater to develop reuse on previously rainfed land or on previously uncultivated land entails a deep alteration of institutional trajectories of water, which is examined in the following section.

Overall, four trends emerge concerning the impacts of wastewater and reuse projects since 1994 on spatial trajectories of water:

(1) The treatment of wastewater and reuse of treated wastewater aims to eliminate surface wastewater flow through the six entry points into Israel that causes a sizeable bill for the PWA.

(2) The projects aim to direct treated wastewater to previously rainfed land or, in the case of the Jordan Valley, to previously uncultivated land.

(3) The projects may inadvertently replenish dried up wells, but none of them aim to recharge the upper unconfined aquifer.

(4) Their alterations of spatial trajectories involve greater flows than those involved in other sectors.

\section{Changes in Institutional Trajectories of Water}

The changes in spatial trajectories of water detailed above have induced drastic changes 
in the institutional trajectories of water. They created, in theory, a new institutional trajectory whereby water would be controlled and managed entirely by the PWA through a public property regime. Extensive field work carried out over several years in the West Bank reveals that reality has differed significantly from this plan.

Municipalities still manage their wells and their WWTPs. The changes in spatial trajectories wiped out many preexisting institutional trajectories whereby grassroot organisations managed part of the spatial trajectory of water through common property regimes. They reduced the flows through other preexisting institutional trajectories. These transformations also inadvertently led to the emergence of new actors, such as unlicenced well owners deploying private property regimes over water, and new, unforeseen institutional trajectories. Recently, some donors have switched to working with municipalities rather than the PWA, transforming the institutional trajectories initially set up by the donors.

The Oslo agreements created the PWA which, for many years, became donors' only interlocutor and main partner. Drilling wells in the deep, confined aquifer allowed supplying the PWA with the only water it controlled at a time when Palestinian well water was overwhelmingly managed by farmer organisations, even when these wells supplied municipalities (Trottier, 1999). Building WWTPs managed by PA institutions and later reuse projects built by the PWA amounted in theory to a vertical integration of water management by the PA. In principle, such development places the institutional trajectory of water entirely in its hands. Water purchased from Mekorot by the PA or abstracted from a PA operated well is distributed to domestic networks. It is then collected as wastewater and channeled to a WWTP which in turns, sells it to farmers. These are chosen according to criteria set by the PA at a price set by municipalities within a range determined by the tariff bylaw of 2013 for growing crops specified by the PA in a location chosen by the PA. A new tariff bylaw of 2018 exists but has yet to be approved (World Bank Group, 2018, p. 22). In practice, such a vertical integration 
did not occur because municipalities kept the control of domestic and wastewater management. Simultaneously, donor projects increased the PA's dependence on Israel since they contributed to its purchasing an increasing amount of water from Mekorot over the years. Thus, donors participated in increasing an institutional flow whereby water was first managed by Israel before being managed by the PWA.

Farmer organisations deploying common property regimes to manage wells and springs tapping the upper, unconfined aquifer have faced drastically reduced flows, often a complete disappearance of the resource (Trottier \& Perrier, 2018) (De Donato, 2018). Storm water sewerage, spring rehabilitation, irrigation network improvement and rehabilitation projects didn't overtly alter the institutional trajectories of the water they managed. But, overall, water projects contributed to reduce the flows replenishing their water source, as detailed in the previous section on spatial trajectories. The treated wastewater generated by WWTP could have been directed to replenish the aquifer feeding wells and springs devoted to irrigation. Instead, it is directed to previously unirrigated land. This has contributed to the demise of many farmer organisations that deployed grassroot common property regimes over springs or wells. Other reasons also contribute to explain the reduction in flows managed by the grassroot organisations predating the PWA. Growing urbanisation, whether in Israeli settlements or in Palestinian towns, increases impermeable surfaces, which interferes with the recharge of the upper unconfined aquifer. Numerous unlicenced wells deploying private property regimes have contributed to drying previously abundant springs. Israeli wells in the West Bank also have an impact. But the changes in spatial trajectories detailed above have undeniably contributed to the demise of many institutional trajectories whereby farmer organisations managed wells and springs for irrigation purposes.

The 2002 Palestinian Water Law (2002) did not even mention farmer organisations managing water locally. Article 31 of the 2014 decree on water mentions 'prior rights from springs or licenced quantity of water extracted from wells' but stops 
short of listing or detailing them (Trottier \& Perrier, 2018). This law and decree do not foresee either a private property regime over water, yet many unlicenced private wells managing water according to a private property regime were legalised by the PWA after they started operating. A legal framework was thus created, with the support of donors, which made these changes in institutional trajectories invisible. Donors didn't plan the demise of existing, sustainable forms of local water management. They usually weren't aware of the impact of their projects over these institutions.

Since 2015, some donors such as French Development Agency and German Kreditanstalt für Wiederaufbau Development Bank have turned to partnering directly with municipalities for large water projects. This now transforms the institutional trajectories of water flows further. But nowhere is the upheaval in institutional trajectories more visible than in the new reuse projects. As irrigation water is directed to previously rainfed or uncultivated land, new actors emerge. Some are agribusinesses (Trottier \& Perrier, 2018). This transformation of agriculture matches what has been described as a neoliberal conflict resolution and state building in the West Bank (Haddad, 2016). This is explored further in the last section of this article.

\section{Changes in sectoral trajectories}

In 1994, upon the arrival of donors in the West Bank, irrigation accounted for the majority of water consumed by Palestinians even though only about $6 \%$ of cultivated land was irrigated. Open air, dirt irrigation channels were common and flood irrigation was still widespread. This meant that a sizeable proportion of spring and well water directed towards irrigation contributed to replenishing the upper, unconfined aquifer and the neighbouring wells that tapped into it. The sectoral trajectory of water thus often entailed being channeled first to an irrigated field before reappearing in a well and being directed to domestic use. Projects targeting irrigation systematically aimed to increase its efficiency at the field level. They reduced the flow of water along any trajectory other than that leading to the cultivated plant. Lankford demonstrated the 
usefulness of the many other trajectories "wasted" water followed in systems deemed inefficient (Lankford, 2013). Considering the transformation to these many trajectories shows that, while, overall, donor led projects didn't aim to transform a sectoral allocation of water among Palestinians, they did transform the sectoral trajectories water followed.

The dominant sectoral trajectory emerging from the sum of donor projects is one whereby water first travels through a domestic use, then reaches a WWTP before being directed to reuse either in irrigation or in industry. This matches the hegemonic representation supporting the "right to water" promoted by the United Nations and brings about territorial change.

\section{Territorial Changes Resulting from 25 Years of Water Aid}

The overall impact of all donor supported water projects is more than the sum total of these projects. This emerges clearly when considering the manner transforming the spatial, institutional and sectoral trajectories of water flows results in territorial transformation. Elden defined territory as a political technology that includes techniques to measure land and to control the terrain (Elden, 2010). Our work shows that this political technology also includes techniques to interact with water flows. Altering the spatial trajectory of water flows entails a transformation of their institutional and sectoral flows. This alters the control actors previously exerted on water, favours some, eliminates others and introduces new ones. In short, while every water project aimed to increase the efficiency of one system over a small scale, it transformed the territory overall by changing the manner Palestinian society interacts with water.

The overwhelming focus on the international scale within the literature on Palestinian water (Elmusa, 1996) (Selby, 2003) (Schlütter, 2005) (Abu-Eid, 2007) (Gasteyer, Isaac, Hillal, \& Walsh, 2012) contributed to painting a situation where Palestinians had no control over their water, as if local institutions didn't exert any management on any portion of the spatial trajectories of water since the beginning of 
the Israeli occupation in 1967. Donors' representation of existing water management stemmed from this literature.

The global literature on water has long recognised the importance of a public participatory approach to illuminate the distribution of the gains and losses of a project across different social groups, before a project is undertaken (Beekman, 2012). But examining the environmental and social impact assessments of water projects carried out in the West Bank show that they tended to consult token groups of concerned parties outside of those asking for a project. Participation can never constitute a silver bullet, in any case, because so called stakeholders usually exclude the views of segments of the population (Tortajada, 2014). Field work showed that few donors became aware of the role of local Palestinian actors, such as farmers. This is a common occurrence wherever communities are heterogeneous and dominated by a local elite whose preference doesn't match that of the grassroots (Platteau, Somville, \& Wahhaj, 2014). The 'water flow analysis' followed in this article shows a territorial change largely unintended by donors.

Donors always proceed with impact assessments before they carry out a project and with an evaluation post-project. The epistemology driving these impact assessments and evaluations embeds the preferences of the donors. What is considered costeffective, environmentally sustainable or in the interest of the public good is determined by the vision of what constitutes development within the donor culture. The vision of what constitutes development is a social construction. It generates many blind spots within these impact assessments and evaluations. Many societal interactions with water are not considered. And every project is considered in a piecemeal fashion, which prevents these assessments and evaluations from including the overall impact on the actors interacting successively with the many flows generated by the one flow under study within one project. 
A careful examination of the types of changes in trajectories shows that those brought about by Palestinian NGOs before 1994 differed significantly from those now brought about by donors, while those brought about by the Israeli Civil Administration were furthered and magnified by donor supported projects. After 1967, Israel introduced reticulation networks to bring domestic water to several Palestinian villages. This work was pursued by donors after 1994. During the first intifada, Palestinian NGOs introduced small, low cost, domestic greywater treatment units. These filtered the greywater from one household to irrigate a few fruit trees next to the house. Such small scale systems were managed by individual households. Such work was less supported by donors after 1994 .

The global economic crisis in 2008 occasioned an unexpected, steep spike in the price of food commodities. It fuelled a drastic increase of export oriented contract farming around the world. This affected Palestinian development projects as well. For instance, the Food and Agriculture Organisation of the United Nations developed the Global Gap certification in Palestinian farms. Such certification allows a farmer to export his produce because it ensures the production process follows recognized standards (Liu, Casey, Cadilhon, Hoejskov, \& Morgan, 2007). Agricultural water projects multiplied (see Figure 3 ) because irrigation stabilises production and allows a farmer to meet the calendars set by contract farming.

The Kerry Plan gathered the tools deemed valid by the existing scientific discourse and policies to construct economic development in a future, independent state of Palestine. As far as agriculture is concerned, important components of this discourse and policies were constructed between 2008 and 2012. This includes a priority given to the development of contract farming for export oriented crops. The Kerry Plan integrated such processes into an economic development plan. The political part of the Kerry Plan collapsed but the agricultural component of its economic component matches many aspects of what now unfolds in the West Bank. 
What sort of territory arises from 25 years of water development in the West Bank? Projects purportedly aimed at supporting the PWA to develop a state that would manage water according to a public property regime. Created by the Oslo agreements in 1994, the PWA emerged in a context where a specific understanding prevailed concerning what constitutes an « efficient » economic management of the environment. The funded projects systematically fitted that vision. This led to the rise of alliances between the PA and private actors on the basis of a neoliberal understanding of efficiency. New actors include small farmers interested in cultivating land, within reuse schemes, which they intend to rent, one hectare at a time, from their owners who used to practice rainfed agriculture and polyactivity. New actors also include agribusinesses that rent large tracts of desert land in the Jordan Valley, 60 hectares at a time, intending to develop irrigation of medjoul dates destined for exportation. Irrigated agriculture in the Jordan Valley is ancient. But for the past hundred years, it was carried out on the basis of water turns from Ein Sultan, Ein Auja and Fassayil springs, or from the 16 springs that used to flow in Ein El Beida, Bardala or Kardala (Trottier, 2013) (Trottier, 2015). These water turns were not monetised. The changes brought to water tenure have transformed the sort of actors who can access water and the purposes for which they access it. Overall, the changes entailed by the water projects undermined the livelihoods that depended on a water tenure that was not monetised. They also increased the dependence of the PWA on water delivered by Mekorot.

\section{Conclusion}

Whether or not the projects concerning water have contributed to the emergence of a Palestinian state is debatable. Overall, they have undermined the grassroot organisations that had developed sustainable water management locally. They have simultaneously contributed to integrating Palestinian society into globalisation. They have introduced a monetised interaction with water where none existed before. They have introduced foreign engineering firms that showcase their technology in the 
wastewater plants they build. They have participated in reducing subsistence agriculture. They have introduced agribusiness led irrigated agriculture in otherwise desert land. The preference of irrigation and reuse projects for the eastern aquifer, where rainfall is lowest, shows the priority given to develop commercial agriculture in the desert in a fashion that mirrors the development of American agriculture. The preference of domestic water projects for the western aquifer contributes to the perpetuation of the existing demographic distribution in the West Bank. Finally, the clustering of these projects close to B and A areas has left a large track of C area undeveloped, open to the development of Israeli settler agriculture and development. The main advantage of the methodology developed here is that it leads to conclusions that are not foreclosed by the underlying theoretical framework. It can be used elsewhere in the world wherever a great number of water projects are carried out within a relatively small space. The evolution of a water sector fuelled by foreign aid is intertwined with the changing nature of a state (Sharma, 2000). This methodology provides a tool to explore such transformation. 


\section{References}

Abu-Eid, A. (2007). Water as a Human Right: The Palestinian Occupied Territories as an Example. International Journal of Water Resources Development, 23(2), 285-301. https://doi.org/10.1080/07900620601097059

Alfarra, A., Kemp-Benedict, E., Hötzl, H., Sader, N., \& Sonneveld, B. (2011). A

Framework for Wastewater Reuse in Jordan: Utilizing a Modified Wastewater Ruse Index. Water Resource Management, 25, 1153-1167. https://doi.org/10.1007/s11269010-9768-8

Bakker, K. (2005). Neoliberalizing nature? Market environmentalism in water supply in England and Wales. Annals of the Association of American Geographers, 95(3), 542565. (ISI:000231225400004).

Beekman, G. B. (2012). Social Change and Water Resource Planning and Development. International Journal of Water Resources Development, 18(1), 183-195.

Boelens, R. (2015). Water, Power and Identity. The cultural politics of water in the Andes. London: Routledge.

Brooks, D. B., Trottier, J., \& Doliner, L. (2013). Changing the nature of transboundary water agreements: the Israeli-Palestinian case. Water International, 38(6), 671-686. https://doi.org/10.1080/02508060.2013.810038

Brynen, R. (2000). A Very Political Economy: Peacebuilding and Foreign Aid in the West Bank and Gaza. Washington DC: United States Institute of Peace Press.

Castro, J. E. (2008). Neoliberal water and sanitation policies as a failed development strategy: lessons from developing countries. Progress in Development Studies, 8(1), 6383. https://doi.org/10.1177/146499340700800107

De Donato, A. (2018). Spring Water : the Lifeblood of the Village of Wādī Fūkīn (West Bank) (PhD Thesis). Université de Milan-Bicocca, Milan, Italy.

Elden, S. (2010). Land, terrain, territory. Progress in Human Geography, 34(6), 799817. https://doi.org/10.1177/0309132510362603

Elmusa, S., S. (1996). Negotiating Water: Israel and the Palestinians. Washington, 
D.C.: Institute for Palestine Studies, Washington DC.

Environmental and Social Impact Assessment for Al-Bireh Reuse Trunk Line to Al-Auja Area. (2016).

Espeland, W. (1998). The Struggle for Water, Politics, Rationality and Identity in the American Southwest. Chicago: The University of Chicago Press.

Feitelson, E., \& Rosenthal, G. (2012). Desalination, space and power: The ramifications of Israel's changing water geography. Geoforum, 43(2), 272-284.

https://doi.org/10.1016/j.geoforum.2011.08.011

Ferguson, J. (1990). The anti-politics machine: “'development,'” depoliticization, and bureaucratic power in Lesotho. Cambridge: Cambridge University Press. (G01214883).

Fischendler, I. (2011). The Politics of Unilateral Environmentalism: Cooperation and Conflict over Water Management along the Israeli-Palestinian Border. Global Environmental Politics, 11(1), 36-61.

Foucault, M. (1969). L'archeologie du savoir. Paris: Gallimard.

Frederiksen, H. D. (2003). Water: Israeli Strategy, Implications for Peace and the Viability of Palestine. Middle East Policy, 10(4), 69-86. https://doi.org/10.1111/j.10611924.2003.00131.x

Gandy, M. (2008). Landscapes of disaster: water, modernity, and urban fragmentation in Mumbai. Environment and Planning A, 40, 108-130.

Gasteyer, S., Isaac, J., Hillal, J., \& Walsh, S. (2012). Water Grabbing in Colonial Perspective: Land and Water in Israel/Palestine. 5(2), 19.

Haddad, T. (2016). Palestine Ltd. Neoliberalism and Nationalism in the Occupied Territory. London: I.B. Tauris.

Harvey, P., Jensen, C. B., \& Morita, A. (2017). Infrastructures and Social Complexity. London; New York: Routledge.

Hodgson, S. (2016). Exploring the Concept of Water Tenure. Rome: Food and Agriculture Organization of the United Nations. 
Israel, \& PLO (Palestine Liberation Organisation). (1995). Interim agreement on the West Bank and the Gaza Strip. Washington DC.

Kaika, M. (2003). Constructing scarcity and sensationalising water politics: 170 days that shook Athens. Antipode, 35(5), 919-954. (ISI:000187790300007).

Karimov, B., Lieth, H., Kurambaeva, M., \& Matsapaeva, I. (2005). The problems of fishermen in the southern Aral Sea region. Mitigation and Adaptation Strategies for Global Change, 10(1), 87-103.

Keating, M., Le More, A., \& Lowe, R. (2005). Aid, diplomacy and facts on the ground: the case of Palestine. London: Chatham House.

Lankford, B. (2013). Resource Efficiency Complexity \& the Commons. London: Routledge.

Le More, A. (2008). International assistance to the Palestinians after Oslo : political guilt, wasted money. London: Routledge.

Liu, P., Casey, S., Cadilhon, J.-J., Hoejskov, P. S., \& Morgan, N. (2007). Regulations, Standards and Certification for Agricultural Exports. Retrieved from http://www.fao.org/3/a-ag130e.pdf Nakhleh, K. (2012). Globalized Palestine. London: The Red Sea Press.

OCHA. (2015). Humanitarian Atlas. United Nations Office for the Coordination of Humanitarian Affairs occupied Palestinian territory.

Palestinian Authority. (2002, July 17). Water Law. Retrieved from http://www.pwa.ps/userfiles/file/water-law-App_-E1.pdf Palestinian Water Authority. (2009). Basic needs and Development Ongoing and Proposed Projects by Governorates.

Palestinian Water Authority. (2011). Annual Status Report on water resources, Water Supply, and Wastewater in the Occupied State of Palestine.

Palestinian Water Authority. (2013). National Water and Wastewater Strategy for Palestine. Retrieved from http://procurement- 
notices.undp.org/view_file.cfm?doc_id=27192

Palestinian Water Authority. (2016). List of Water Projects in the West Bank.

Platteau, J.-P., Somville, V., \& Wahhaj, Z. (2014). Elite capture through information distortion: A theoretical essay. Journal of Development Economics, 106(6), 250-263. https://doi.org/10.1016/j.jdeveco.2013.10.002

Reisner, M. (1993). Cadillac Desert. The American West and its Disappearing Water. New York: Penguin Books.

Schlütter, B. (2005). Water Rights in the West Bank and in Gaza. Leiden Journal of International Law, 18(03), 621. https://doi.org/10.1017/S0922156505002906

Selby, J. (2003). Water, Power \& Politics in the Middle East The Other IsraeliPalestinian Conflict. IB Tauris.

Sharma, S. (2000). Foreign Aid and Institutional Plurality: The Domestic Water Sector in Nepal. International Journal of Water Resources Development, 16(1), 119-130.

Swyngedouw, E. (2015). Liquid Power. Contested Hydrol-Modernities in Twentieth Century Spain. Cambridge, MA: MIT Press.

Tomeizeh, A. H., \& Naslund, S. (2006). Water Rights. In The Lower Jordan River Basin Programme Publications. Wadi el-Far'a Project Report: An Environmental Assessment of the Wadi el-Far'a Watershed. Ramallah: Bir Zeit University. Tortajada, C. (2014). Water infrastructure as an essential element for human development. International Journal of Water Resources Development, 30(1), 8-19. Trottier, J. (1999). Hydropolitics in the West Bank and Gaza Strip. Jerusalem: PASSIA. Trottier, J. (2013). The social construction of water management at the intersection of international conflict The Case of Al Auja. Eurorient, (44), 161-181.

Trottier, J. (2015). Le rapport à l'eau et à la terre dans la construction de territoires multisitués: le cas palestinien. L'Espace Géographique, 2, 103-114.

Trottier, J., \& Perrier, J. (2017). Challenging the Coproduction of Virtual Water and Palestinian Agriculture. Geoforum, 87, 85-94. 
Trottier, J., \& Perrier, J. (2018). Water driven Palestinian agricultural frontiers: the global ramifications of transforming local irrigation. Journal of Political Ecology, 25(1), 292-311.

Uvin, P. (1998). Aiding Violence, The Development Enterprise in Rwanda. West Hartford, USA: Kumarian Press.

World Bank. (2009). Assessment of restriction on Palestinian water sector development. Retrieved from https://siteresources.worldbank.org/INTWESTBANKGAZA/Resources/WaterRestrictio nsReport18Apr2009.pdf

World Bank Group. (2018). Securing Water for Development in West Bank and Gaza. Zeitoun, M. (2008). Water policy for sustainable development. Environment and Planning C-Government and Policy, 26(5), 1040-1041. (ISI:000260712800016). 
Map 1 - The three aquifers and their drainage zones in the West bank

Map 2 - Transboundary wastewater and Israeli wastewater treatment plants

Figure 1 - Example of institutional trajectories of water flows

Table 1 - Information on the three databases

Table 2 - Number of domestic, agricultural water and wastewater projects according to the different databases

Figure 2 - Evolution of the number of water projects according to the year they were proposed from 1994 to 2016 (PWA 2016)

Figure 3

Figure 3 (a) - Evolution of the number of domestic water projects for each aquifer from 1994 to 2016 (PWA 2016)

Figure 3 (b) - Evolution of the number of agricultural water projects for each aquifer from 1994 to 2016 (PWA 2016)

Figure 3 (c) - Evolution of the number of wastewater projects for each aquifer from 1994 to 2016 (PWA 2016)

Table 3 - Type and proportion of funded and unfunded domestic, agricultural water and wastewater projects (PWA 2016)

Map 3 - Status of the water projects in the West Bank from 1994 to 2016 (PWA 2016)

Table 4 - Number of agricultural water projects per aquifer (PWA 2016)

Table 5 - Present and planned treated wastewater outflow and treated wastewater reuse flows for existing WWTPs and WWTPs under construction Map 4 - Existing wastewater treatment plants and proposed or active treated wastewater reuse projects in the West Bank

Appendix 1 - Detailed methodology

Appendix 2 - Methodology for wastewater treatment projects 